\title{
The Significance of Neutrophil-to-Lymphocyte Ratio and Platelet-to-Lymphocyte Ratio as Markers for Prognosis in Idiopathic Sudden Sensorineural Hearing Loss
}

\author{
Keun-Ik Yi, Se-Joon Oh, Sung-Won Choi, Seon-Lin Kim, Soo-Keun Kong, and Eui-Kyung Goh \\ Department of Otorhinolaryngology-Head and Neck Surgery, Pusan National University School of Medicine and \\ Medical Research Institute, Busan, Korea
}

\section{돌발성 난청의 예후 예측 인자로서 호중구-림프구 비율 및 혈소판-림프구 비율의 의미}

이근익 · 오세준 · 최성원 · 김선린 · 공수근 · 고의경

부산대학교 의과대학 이비인후과학교실

\author{
Received June 7, 2017 \\ Revised August 24, 2017 \\ Accepted September 13, 2017 \\ Address for correspondence \\ Eui-Kyung Goh, MD, PhD \\ Department of Otorhinolaryngology- \\ Head and Neck Surgery, \\ Pusan National University \\ School of Medicine and \\ Medical Research Institute, \\ 179 Gudeok-ro, Seo-gu, \\ Busan 49241, Korea \\ Tel +82-51-240-7335 \\ Fax $+82-51-246-8668$ \\ E-mail gohek@pusan.ac.kr
}

Background and Objectives The cause of idiopathic sudden sensorineural hearing loss (ISSNHL) is still unclear, but recently, chronic inflammation and thrombosis have received attention. The neutrophil-to-lymphocyte ratio (NLR) and platelet-to-lymphocyte ratio (PLR) are some of the markers that show the state of inflammation and ischemia, which are measured routinely in the complete blood cell count $(\mathrm{CBC})$ test. The aim of this study were to investigate the relevance of NLR and PLR with ISSNHL.

Subjects and Method Enrolled in our retrospective analysis were 103 patients diagnosed with ISSNHL. Blood samples were taken from the patients and hearing assessments were performed. NLR and PLR were calculated using the CBC results. Then the patients were divided into 4 groups using Sigel's criteria according to their response to the treatment, which were again classified two groups, the "recovered" and "unrecovered" group.

Results NLR, PLR, and neutrophil values of the unrecovered group were significantly higher than the recovered group ( $p=0.002, p=0.009$, and $p=0.038$, respectively). On the other hand, lymphocyte values were significantly higher in the recovered group $(p=0.007)$. After adjustment in a multivariate logistic regression analysis, NLR was associated with the recovery of ISSNHL (Odds ratio=1.290, $p=0.042$ ). In addition, NLR and PLR values were also significantly different between the groups classified by the Sigel's criteria ( $p=0.009$ and $p=0.029$, respectively).

Conclusion PLR values may be useful in predicting hearing recovery after treatment in patients with ISSNH. It is also expected to be a potential marker for predicting the prognosis and determining further treatment options. Korean J Otorhinolaryngol-Head Neck Surg 2018;61(7):333-40

Key Words Laboratory marker · Prognosis · Sudden sensorineural hearing loss.

\section{서 론}

돌발성 난청(idiopathic sudden sensorineural hearing loss,

This is an Open Access article distributed under the terms of the Creative Commons Attribution Non-Commercial License (https://creativecommons.org/licenses/by-nc/4.0) which permits unrestricted non-commercial use, distribution, and reproduction in any medium, provided the original work is properly cited.
ISSNHL)의 일반적 정의는 72시간 이내에 급성으로 발생한 3 개의 연속된 주파수에서의 $30 \mathrm{~dB}$ 이상의 청력손실을 의미 한다.,2) 돌발성 난청은 영구적인 청력 장애가 생길 수 있으므 로 조기에 원인 및 예후와 관련하여 정확한 평가를 시행하고 적절한 치료의 선택이 중요하다. 돌발성 난청의 병인으로는 바이러스 감염, 순환 장애, 면역 관련 질환 등이 제시되었으 
나 현재까지 정설로 받아들일 만한 결정적인 증거는 나오지 않았다. ${ }^{3-6)}$ 최근에는 돌발성 난청의 원인으로 만성 염증에 관 심을 두고 있다.,7) 만성 염증은 미세혈관 손상을 일으켜 죽종 (thrombus)이 형성되고 이러한 과정을 통해 직접적으로 허혈 의 위험성을 높인다. ${ }^{8}$

전혈구검사(complete blood cell count)는 환자의 일반적인 건강 상태와 염증 정도를 평가하는데 유용한 정보를 제공한다. 호중구-림프구 비율(neutrophil-to-lymphocyte ratio, NLR) 과 혈소판-림프구 비율(platelet-to-lymphocyte ratio, PLR)은 전혈구검사에서 쉽게 계산할 수 있으며, 전신적인 염증 상태 및 혈전 발생에 대한 표지자로 최근 제시되고 있다.9) 또한 NLR 은 심혈관 질환의 발생과 예후를 예측할 수 있는 유용한 독립 인자로 알려졌으며, PLR은 말초동맥 폐쇄 질환 환자에서 죽 상동맥경화의 나뺀 예후와 관련이 있는 것으로 밝혀졌다. ${ }^{10,11}$

돌발성 난청의 회복과 관계된 인자에 대해서는 많이 보고되 고 있다. 특히 나이, 초기 청력손실 정도, 청력도의 형태, 발생 후 치료까지의 기간, 동반 증상, 특히 현훈 등이 청력의 회복 에 영향을 주는 인자로 알려져 있으며 지금도 예후에 관한 연구가 계속적으로 보고되고 있다. ${ }^{12-19)}$

최근 돌발성 난청의 진단 및 예후와 관련하여 NLR과 PLR 에 대한 연구가 진행되고 있다. Özler ${ }^{20)}$ 는 돌발성 난청 환자 에서 NLR의 값은 대조군에 비해 유의하게 높은 결과를 보 였으며, 이것은 와우의 허혈에 의한 이차적 염증 과정과 관련 되어 있다고 기술하였으며, Ulu 등1)은 NLR이 돌발성 난청 환자의 진단과 회복 정도를 예측하는 인자로서 고려되어야 한다고 하였다. 또한 Seo 등2)은 NLR 외에 PLR도 돌발성 난청의 진단에 관련된 표지자로 의미가 있다고 하였다.

본 연구에서는 돌발성 난청의 예후와 관계된 여러 가지 인 자를 분석하고, 특히 NLR, PLR의 새로운 의미를 평가하고 돌발성 난청의 회복 정도와 혈액검사 결과와의 관련성에 대 해 알아보고자 한다.

\section{대상 및 방법}

\section{대 상}

부산대학교병원에서 2011년 1월부터 2015년 3월까지 돌발 성 난청으로 진단받고 입원 치료를 받은 340 명의 환자를 대 상으로 하여 후향적으로 의무기록을 분석하였다. 돌발성 난 청을 72 시간 이내에 3 개의 연속된 주파수에서 갑자기 발생 한 $30 \mathrm{~dB}$ 이상의 한쪽 청력손실로 정의하였다. ${ }^{23)}$ 당뇨, 고혈 압, 고지혈증, 관상동맥 질환, 급성 혹은 만성 신부전, 만성 간 질환, 만성 폐쇄성 폐 질환, 결체조직 질환의 기저질환을 가지 고 있는 환자는 제외하였고, 그 외 급성 감염 증상이 있거나 만
성 중이염, 메니에르병과 같은 이과적 질환을 않고 있는 경우, 급성 청력 저하나 음향 외상의 병력이 있었던 경우, 임신 중인 경우도 배제하였다. 입원 치료 이전 steroid 제제를 복용하였 던 환자도 제외하였다. 첫 방문 시 혈액검사를 위해 채혈을 시 행하였고 청력손실 정도를 파악하기 위해 표준순음청력검사 (pure tone audiometry)를 시행하였다. 자기공명영상(magnetic resonance imaging) 촬영을 시행한 환자만 연구 대상에 포함 되었으며 검사 시행 후 청력 저하를 유발할 수 있는 뇌병변이 발견된 경우는 연구 대상에서 제외하였다. 최종적으로 103명 의 환자가 연구에 포함되었고 환자는 입원 후 침상 안정을 취 하고 저분자 텍스트란 및 혈관확장제, 혈류순환개선제 처방을 받았다. 주된 치료로는 methylprednisolone $48 \mathrm{mg}$ 을 10일간 경구 복용하였고, 이후 4일에 걸쳐 $32,24,16,8 \mathrm{mg}$ 순으로 tapering하였다. 치료 도중 청력이 완전회복된 경우 다음 날 부터 tapering 후 복용 중단하였으며, 치료 시작 후 4일째 청력 검사상 Siegel's criteria IV ${ }^{24}$ 에 해당하는 경우에는 고실 내 스 테로이드 주입술(intratympanic steroid injection)을 이틀에 한 번 간격으로 추가 시행하였다.

\section{혈액검사}

모든 대상 환자에게서 첫 방문 후 입원 시 채혈검사를 시행 하였다. 검사 항목으로는 전혈구검사로 백혈구(white blood cells) 및 혈소판(platelet) 수를 측정하였고, 백혈구 중 세부적 으로 호중구, 림프구, 단핵구를 포함한 백혈구 백분율을 산정 하였다. Viral marker 검사로 herpes simplex virus(HSV), varicella zoster virus(VZV), cytomegalovirus(CMV), influenza virus (A, B), human immunodeficiency virus (HIV)에 대 한 검사를 진행하였다. 그 외 당화혈색소( $\mathrm{HbA1C})$, 아스파르 테이트아미노전달효소(aspartate aminotransferase, AST), 알라닌아미노전달효소(alanine aminotransferase, ALT), 적 혈구 침강 속도(erythrocyte sedimentation rate, ESR), C 반 응성 단백(C-reactive protein, CRP), 혈액 요소 질소(blood urea nitrogen), 크레아티닌(creatinine), 총 콜레스테롤(total cholesterol), 유리티록신(free thyroxine) 검사 등을 시행하 였다. NLR 및 PLR은 호중구, 혈소판 및 림프구 수를 이용하 여 계산하였다.

\section{청각학적 평가}

청력검사는 입원 기간 동안 표준순음청력검사를 격일로 시 행하였고, 청성뇌간반응검사(auditory brain response)를 1회 시행하였다. 퇴원 후에는 1 개월 간격으로 3 개월까지 청력 변 화를 관찰하였다. 청력 회복의 판정은 순음청력검사에서 $0.5,1,2 \mathrm{~K}$ 를 이용한 4분법을 사용하여 그 평균값을 비교하였 
고, 치료 시작 3 개월째 가장 마지막 순음청력검사를 기준으로 하였다. 청력 회복의 판정은 Siegel ${ }^{24}$ 의 분류를 따라 최종 25 $\mathrm{dB}$ 역치 이내로 청력 호전이 있는 경우를 완전회복군(complete recovery, I), $15 \mathrm{~dB}$ 이상 청력 호전이 있고 최종 $25 \sim 45 \mathrm{~dB}$ 범 위의 청력 역치인 경우를 부분회복군(partial recovery, II), $15 \mathrm{~dB}$ 이상 청력 호전이 있고 최종 $45 \mathrm{~dB}$ 이상 범위의 청력 역 치인 경우를 경도회복군(slight recovery, III), 그리고 $15 \mathrm{~dB}$ 미만으로 청력 호전이 있거나 최종 $75 \mathrm{~dB}$ 이상 범위의 청력 역치인 경우를 비회복군(no improvement, IV)으로 분류하였 고, 청력 회복의 기준은 경도회복군 이상을 회복군으로 하여 비회복군과 비교하였다.

\section{통계 분석}

통계 분석에서, 연속형 변수는 평균ㅍ표준 편차로 요약하였 고, 자료의 비교는 Mann-Whitney U-test와 Kruskal-Wallis test를 이용하였다. 범주형 변수는 빈도와 백분율로 나타내었 고, 자료 비교는 chi-square test와 Fisher's exact test를 이용 하였다. 통계 분석은 SPSS 21.0(SPSS Software, IBM Corp., Armonk, NY, USA)을 이용하였으며, 유의 수준은 $p$ value 0.05 미만으로 정의하였다.

\section{결 과}

103 명의 돌발성 난청 환자들을 분석한 결과, Table 1 과 같 이 Sigel의 분류로 완전회복 44 명 $(42.7 \%)$, 부분회복 17 명 (16.5\%), 경도회복 17명(16.5\%), 비회복군은 25명(24.3\%)이었 다. 따라서 회복군은 총 78명(75.7\%)이었다.

회복군과 비회복군을 비교했을 때, 성별, 연령, 백혈구, 혈 소판, 당화혈색소, 혈액 요소 질소, 크레아티닌, AST, ALT, 총 콜레스테롤, 적혈구 침강 속도, $\mathrm{C}$ 반응성 단백, 유리티록신 값 및 viral marker에서는 차이를 보이지 않았다(Table 2). 회복 군과 비회복군에서 호중구 수는 각각 $5.06 \pm 2.37,6.78 \pm 3.54$ 로 의미 있는 차이를 보였다 $(p=0.038)$. 회복군과 비회복군에 서 림프구 수는 $2.18 \pm 0.85,1.64 \pm 0.66$ 으로 차이가 있었다 $(p=$ 0.007). NLR은 회복군에서는 $2.89 \pm 2.27$, 비회복군에서는 $5.01 \pm 3.50(p=0.002), \mathrm{PLR}$ 은 회복군에서는 $137.49 \pm 68.56$, 비 회복군에서는 $182.11 \pm 90.88(p=0.009)$ 으로 통계적으로 각각
의미 있는 차이를 보였다. 동반 증상에 따른 회복 정도를 평가 했을 때, 이명 유무는 차이가 없었으며, 현훈이 동반된 경우는 비회복군에서 $44.0 \%$ 로 회복군(21.8\%)에 비해 유의하게 높은 비율을 보였다 $(p=0.030)$.

또한, Siegel의 분류로 I군에서 $\mathbb{I V}$ 군까지 각 군에 대한 비 교 분석을 시행하였다(Table 3). NLR은 I군 $3.00 \pm 2.51$, II군

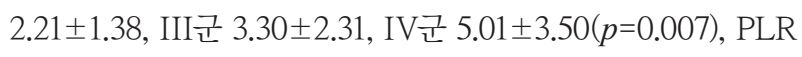
은 I군 $140.88 \pm 69.15$, II군 $115.99 \pm 57.10$, III군 $150.23 \pm$ 76.26 , IV군 $182.11 \pm 90.88(p=0.029)$ 로 유의한 차이를 보였 다. 이것은 I군 및 II군과 IV군 사이에서 유의한 결과를 보였 다(Fig. 1). 하지만 viral marker는 각 군 간 유의한 결과를 보 이지는 않았다 $(p=0.241)$. 그 외 동반 증상으로 현훈의 유무는 각 군 간 유의한 차이가 있었다 $(p=0.008)$.

다중 로지스틱 회귀 분석(multivariate logistic regression) 을 이용하여 돌발성 난청의 회복에 대한 각각의 변수를 분석 하였을 때, 보정 후의 변수값은 NLR이 odds ratio(OR) 1.359 $(p=0.020)$ 로 유의한 결과를 보였다(Table 4). 그리고 현훈이 동반된 경우가 예후가 더 좋지 않은 것으로 나타났으나, PLR 및 viral marker는 통계적으로 의미 있는 결과를 보이지 않 았다.

난청이 발생하고 치료를 시작할 때까지의 시간은 회복군에 서는 $4.77 \pm 2.87$ 일, 비회복군에서는 $7.60 \pm 7.78$ 일 $(p=0.242)$ 로 나타났고, 1 주일 이내에 치료를 시작한 군과 1 주일 이후 치료 를 시작한 군으로 나누었을 때는 두 군 간 차이는 통계적으로 유의하지는 않았으나 1 주일 이내에 치료 시 회복군의 비율이 더 높은 경향을 보였다(76.9\% vs. 60.0\%; $p=0.098)$. 그리고 현훈이 동반된 경우가 회복군(21.8\%)보다 비회복군(44.0\%) 에서의 비율이 유의하게 높게 나왔다 $(p=0.030)$.

환자의 치료에 있어서 스테로이드를 경구 복용하거나 고실 내 주입술을 병용한 경우로 나눌 수 있는데, methylprednisolone을 경구 복용만 한 경우는 전체 103명 중 62명(60.2\%) 이고 경구 복용과 고실 내 스테로이드 주입술을 같이 시행한 경우는 41명(39.8\%)이었다. 고실 내 스테로이드 주입술을 병행 한 경우 최종적으로 6명(14.6\%)이 완전회복되었고, 8명(19.5\%) 이 부분회복, 13 명(31.7\%)이 경도회복, 14 명(34.1\%)이 회복되 지 않았다.

Table 1. The demographic characteristics of the study populations

\begin{tabular}{lccc}
\hline Group & Number of patients (\%) & Siegel's criteria & Number of patients (\%) \\
\hline Recovered & $78(75.7)$ & I & $44(42.7)$ \\
& & II & $17(16.5)$ \\
& & III & $17(16.5)$ \\
Unrecovered & $25(24.3)$ & IV & $25(24.3)$ \\
\hline
\end{tabular}




\section{고 찰}

돌발성 난청의 정확한 병인은 아직까지 밝혀진 바가 없으나 내이의 순환 장애설와 바이러스 감염설이 가장 주목받고 있 으며, ${ }^{45)}$ 그 외 내이 압력 변화에 의한 와우막 파열, 자가면역 질환, 세균 감염, 다발성경화증, 이독성 약물, 종양, 음향성 외상, 알레르기, 매독, 지방색전증 등이 거론되고 있다. ${ }^{6,25,26)}$

그중 바이러스 감염설을 살펴보면, 이전 연구에서 돌발성 난청 환자의 외림프에서 mumps virus 가 배양되었으며, ${ }^{27)}$ 혈
청검사상에서도 돌발성 난청 환자의 70\%에서 herpes virus 를 발견할 수 있었다. ${ }^{28)}$ 이것은 바이러스 자체가 내이 속으로 침입하여 내이세포에 직접적인 손상을 줄 수 있으며 간접적 으로 혈관조(stria vascularis)나 나선혈관(spiral vessel)의 혈 관 내 혈액 응고를 유발하고, 내림프액의 생화학적인 변화를 통해 내이 유모세포에 가역적인 손상을 입힐 수 있다고 설명 하였다. ${ }^{29)}$ 또한 돌발성 난청 및 혈관 장애의 병력이 있는 환자 의 사후 측두골 분석에서 돌발성 난청 환자군에서 perilymph fibrosis, ganglion cells의 발현이 적게 관찰되고 spiral lig-

Table 2. The demographic and clinical characteristics of the recovered group and unrecovered group

\begin{tabular}{|c|c|c|c|}
\hline Variables & Recovered group $(n=78)$ & Unrecovered group $(\mathrm{n}=25)$ & $p$ value \\
\hline Age $(y r)$ & $44.60 \pm 15.66$ & $46.04 \pm 16.49$ & 0.590 \\
\hline \multicolumn{4}{|l|}{$\operatorname{Sex}(n) *$} \\
\hline Male & $23(29.5 \%)$ & 7 (28.0\%) & 0.887 \\
\hline Female & $55(70.5 \%)$ & $18(72.0 \%)$ & \\
\hline $\mathrm{WBC}\left(10^{3} / \mathrm{UL}\right)$ & $7.78 \pm 2.59$ & $8.90 \pm 3.52$ & 0.167 \\
\hline Neutrophil $\left(10^{3} / \mathrm{UL}\right)$ & $5.06 \pm 2.37$ & $6.78 \pm 3.54$ & $0.038^{\dagger}$ \\
\hline Lymphocyte $\left(10^{3} / \mathrm{uL}\right)$ & $2.18 \pm 0.85$ & $1.64 \pm 0.66$ & $0.007^{\dagger}$ \\
\hline NLR & $2.89 \pm 2.27$ & $5.01 \pm 3.50$ & $0.002^{\dagger}$ \\
\hline Platelet $\left(10^{3} / \mathrm{UL}\right)$ & $253.54 \pm 52.32$ & $252.76 \pm 46.07$ & 0.698 \\
\hline PLR & $137.49 \pm 68.56$ & $182.11 \pm 90.88$ & $0.009+$ \\
\hline $\mathrm{Hb} \mathrm{AlC}$ & $5.53 \pm 0.39$ & $5.50 \pm 0.32$ & 0.721 \\
\hline BUN (mg/dL) & $15.06 \pm 3.74$ & $16.30 \pm 4.42$ & 0.290 \\
\hline $\mathrm{Cr}(\mathrm{mg} / \mathrm{dL})$ & $0.73 \pm 0.14$ & $0.73 \pm 0.14$ & 0.823 \\
\hline AST $(U / L)$ & $21.32 \pm 8.33$ & $19.44 \pm 6.43$ & 0.241 \\
\hline $\operatorname{ALT}(\mathrm{U} / \mathrm{L})$ & $21.01 \pm 11.39$ & $22.00 \pm 13.62$ & 0.703 \\
\hline T. cholesterol & $204.09 \pm 40.17$ & $216.28 \pm 41.50$ & 0.236 \\
\hline ESR & $13.28 \pm 11.35$ & $15.64 \pm 13.43$ & 0.484 \\
\hline CRP & $0.07 \pm 0.14$ & $0.08 \pm 0.11$ & 0.577 \\
\hline FT4 & $1.26 \pm 0.21$ & $1.29 \pm 0.22$ & 0.582 \\
\hline \multicolumn{4}{|l|}{ Viral marker* } \\
\hline+ & $8(10.3 \%)$ & $3(12.0 \%)$ & 0.726 \\
\hline- & $70(89.7 \%)$ & $22(88.0 \%)$ & \\
\hline \multicolumn{4}{|l|}{ Side of lesion* } \\
\hline Right & $37(47.4 \%)$ & $9(36.0 \%)$ & 0.317 \\
\hline Left & $41(52.6 \%)$ & $16(64.0 \%)$ & \\
\hline Days from onset to treatment* & $4.77 \pm 2.87$ & $7.60 \pm 7.78$ & 0.242 \\
\hline Less than a week & $60(76.9 \%)$ & $15(60.0 \%)$ & 0.098 \\
\hline More than a week & $18(23.1 \%)$ & $10(40.0 \%)$ & \\
\hline \multicolumn{4}{|l|}{ Tinnitus* } \\
\hline+ & $64(82.1 \%)$ & $20(80.0 \%)$ & 0.818 \\
\hline- & $14(17.9 \%)$ & $5(20.0 \%)$ & \\
\hline \multicolumn{4}{|l|}{ Vertigo* } \\
\hline+ & $17(21.8 \%)$ & $11(44.0 \%)$ & $0.030^{\dagger}$ \\
\hline- & $61(78.2 \%)$ & $14(56.0 \%)$ & \\
\hline
\end{tabular}

Statistics were tested by Mann-Whitney U-test, chi-square test, Fisher's exact test. All parameters were expressed as mean \pm standard deviation unless otherwise stated. *data were expressed as number (\%), ${ }^{\dagger} p<0.05$ value was accepted as significant level. yr: year, WBC: white blood cells, NLR: neutrophil-to-lymphocyte ratio, PLR: platelet-to-lymphocyte ratio, BUN: blood urea nitrogen, Cr: creatinine, AST: aspartate aminotransferase, ALT: alanine aminotransferase, T. cholesterol: total cholesterol, ESR: erythrocyte sedimentation rate, CRP: C-reactive protein, FT4: free thyroxine 
ament 및 hair cell의 생존율이 더 증가되어 있으며, tectorial membrane의 이상이 더 만연해있다는 것을 밝혀냈다. ${ }^{30)}$ Corti 기관의 위축 및 cochlear ganglion의 소실이 돌발성 난청 환 자의 가능 흔한 조직병리학적 소견이고 이는 이미 알려져 있 는 바이러스 질환과 유사하며 따라서 바이러스 감염에 의한 변화임을 시사하였다. ${ }^{31-33)}$ 이러한 증거들을 근거로 돌발성 난
청의 치료에 Acyclovir와 같은 항바이러스 제제를 사용하기 도 한다. ${ }^{6}$

돌발성 난청과 관계 있는 것으로 현재까지 보고된 바이러 스들로는 mumps virus, cytomegalovirus, rubella virus, varicella zoster virus, herpes simplex virus, parainfluenza virus, adenovirus type 3, Lassa fever, Ebstein-Barr virus,

Table 3. The demographic and clinical characteristics of patients according to Siegel's criteria

\begin{tabular}{|c|c|c|c|c|c|}
\hline Variables & I $(n=44)$ & II $(n=17)$ & III $(n=17)$ & IV $(n=25)$ & $p$ value \\
\hline Age (yr) & $40.86 \pm 16.93$ & $50.12 \pm 14.25$ & $48.76 \pm 10.86$ & $46.04 \pm 16.49$ & 0.085 \\
\hline \multicolumn{6}{|l|}{$\operatorname{Sex}(n)^{*}$} \\
\hline Male & $15(34.1 \%)$ & $4(23.5 \%)$ & $4(23.5 \%)$ & $7(28.0 \%)$ & 0.516 \\
\hline Female & $29(65.9 \%)$ & $13(76.5 \%)$ & $13(76.5 \%)$ & $18(72.0 \%)$ & \\
\hline $\operatorname{WBC}\left(10^{3} / \mathrm{UL}\right)$ & $7.89 \pm 2.46$ & $7.71 \pm 2.48$ & $7.56 \pm 3.12$ & $8.90 \pm 3.52$ & 0.354 \\
\hline Neutrophil $\left(10^{3} / \mathrm{LL}\right)$ & $5.14 \pm 2.36$ & $4.73 \pm 2.16$ & $5.21 \pm 2.68$ & $6.78 \pm 3.54$ & 0.170 \\
\hline Lymphocyte (103/uL) & $2.20 \pm 0.90$ & $2.46 \pm 0.85$ & $1.83 \pm 0.59$ & $1.64 \pm 0.66$ & $0.009 \neq$ \\
\hline $\mathrm{T}^{\dagger}$ & $a, b$ & $a$ & $b, c$ & c & \\
\hline \multirow[t]{2}{*}{ NLR } & $3.00 \pm 2.51$ & $2.21 \pm 1.38$ & $3.30 \pm 2.31$ & $5.01 \pm 3.50$ & $0.007 \ddagger$ \\
\hline & a & a & $a, b$ & b & \\
\hline Platelet (103/uL) & $260.41 \pm 57.58$ & $248.47 \pm 43.19$ & $240.82 \pm 45.46$ & $252.76 \pm 46.07$ & 0.573 \\
\hline \multirow[t]{2}{*}{ PLR } & $140.88 \pm 69.15$ & $115.99 \pm 57.10$ & $150.23 \pm 76.26$ & $182.11 \pm 90.88$ & $0.029 \ddagger$ \\
\hline & $a$ & $a$ & $a, b$ & $\mathrm{~b}$ & \\
\hline $\mathrm{Hb} \mathrm{AlC}$ & $5.53 \pm 0.41$ & $5.53 \pm 0.33$ & $5.55 \pm 0.40$ & $5.50 \pm 0.32$ & 0.967 \\
\hline BUN (mg/dL) & $14.87 \pm 3.97$ & $14.65 \pm 3.59$ & $15.99 \pm 3.28$ & $16.30 \pm 4.42$ & 0.442 \\
\hline $\mathrm{Cr}(\mathrm{mg} / \mathrm{dL})$ & $0.73 \pm 0.13$ & $0.68 \pm 0.15$ & $0.76 \pm 0.15$ & $0.73 \pm 0.14$ & 0.619 \\
\hline AST (U/L) & $21.32 \pm 8.58$ & $20.12 \pm 6.87$ & $22.53 \pm 9.23$ & $19.44 \pm 6.43$ & 0.387 \\
\hline $\mathrm{ALT}(\mathrm{U} / \mathrm{L})$ & $21.48 \pm 12.81$ & $21.53 \pm 11.45$ & $19.29 \pm 6.94$ & $22.00 \pm 13.62$ & 0.972 \\
\hline T. cholesterol & $205.98 \pm 41.42$ & $198.12 \pm 40.85$ & $205.18 \pm 37.90$ & $216.28 \pm 41.50$ & 0.633 \\
\hline ESR & $12.30 \pm 11.63$ & $16.29 \pm 12.01$ & $12.82 \pm 10.01$ & $15.64 \pm 13.43$ & 0.471 \\
\hline CRP & $0.08 \pm 0.18$ & $0.06 \pm 0.06$ & $0.06 \pm 0.09$ & $0.08 \pm 0.11$ & 0.737 \\
\hline FT4 & $1.26 \pm 0.23$ & $1.26 \pm 0.17$ & $1.28 \pm 0.21$ & $1.29 \pm 0.22$ & 0.948 \\
\hline \multicolumn{6}{|l|}{ Viral marker* } \\
\hline+ & $3(6.8 \%)$ & $1(5.9 \%)$ & $4(23.5 \%)$ & $3(12.0 \%)$ & 0.241 \\
\hline- & $41(93.2 \%)$ & $16(94.1 \%)$ & $13(76.5 \%)$ & $22(88.0 \%)$ & \\
\hline \multicolumn{6}{|l|}{ Side of lesion* } \\
\hline Right & $24(54.5 \%)$ & $11(64.7 \%)$ & $2(11.8 \%)$ & $9(36.0 \%)$ & $0.022^{\ddagger}$ \\
\hline Left & $20(45.5 \%)$ & $6(35.3 \%)$ & $15(88.2 \%)$ & $16(64.0 \%)$ & \\
\hline $\begin{array}{l}\text { Days from onset to treat- } \\
\text { ment* }\end{array}$ & $4.80 \pm 2.99$ & $5.41 \pm 2.69$ & $4.06 \pm 2.73$ & $7.60 \pm 7.78$ & 0.238 \\
\hline Less than a week & $35(79.5 \%)$ & $11(64.7 \%)$ & $14(82.4 \%)$ & $15(60.0 \%)$ & 0.165 \\
\hline More than a week & $9(20.5 \%)$ & $6(35.3 \%)$ & $3(17.6 \%)$ & $10(40.0 \%)$ & \\
\hline \multicolumn{6}{|l|}{ Tinnitus* } \\
\hline+ & $32(72.7 \%)$ & $17(100.0 \%)$ & $15(88.2 \%)$ & $20(80.0 \%)$ & 0.383 \\
\hline- & $12(27.3 \%)$ & $0(0.0 \%)$ & $2(11.8 \%)$ & 5 (20.0\%) & \\
\hline \multicolumn{6}{|l|}{ Vertigo* } \\
\hline+ & $8(18.2 \%)$ & $2(11.8 \%)$ & $7(41.2 \%)$ & 11 (44.0\%) & $0.008^{\ddagger}$ \\
\hline- & $36(81.8 \%)$ & $15(88.2 \%)$ & $10(58.8 \%)$ & $14(56.0 \%)$ & \\
\hline
\end{tabular}

Statistical significance were tested by Kruskal-wallis test and chi-square test. All parameters were expressed as mean \pm standard deviation unless otherwise stated. *data were expressed as number (\%), the same letters indicate non-significant difference between groups, $\neq \mathrm{p}<0.05$ value was accepted as significant level. yr: year, WBC: white blood cells, NLR: neutrophil-to-lymphocyte ratio, PLR: platelet-to-lymphocyte ratio, BUN: blood urea nitrogen, Cr: creatinine, AST: aspartate aminotransferase, ALT: alanine aminotransferase, T. cholesterol: total cholesterol, ESR: erythrocyte sedimentation rate, CRP: C-reactive protein, FT4: free thyroxine 


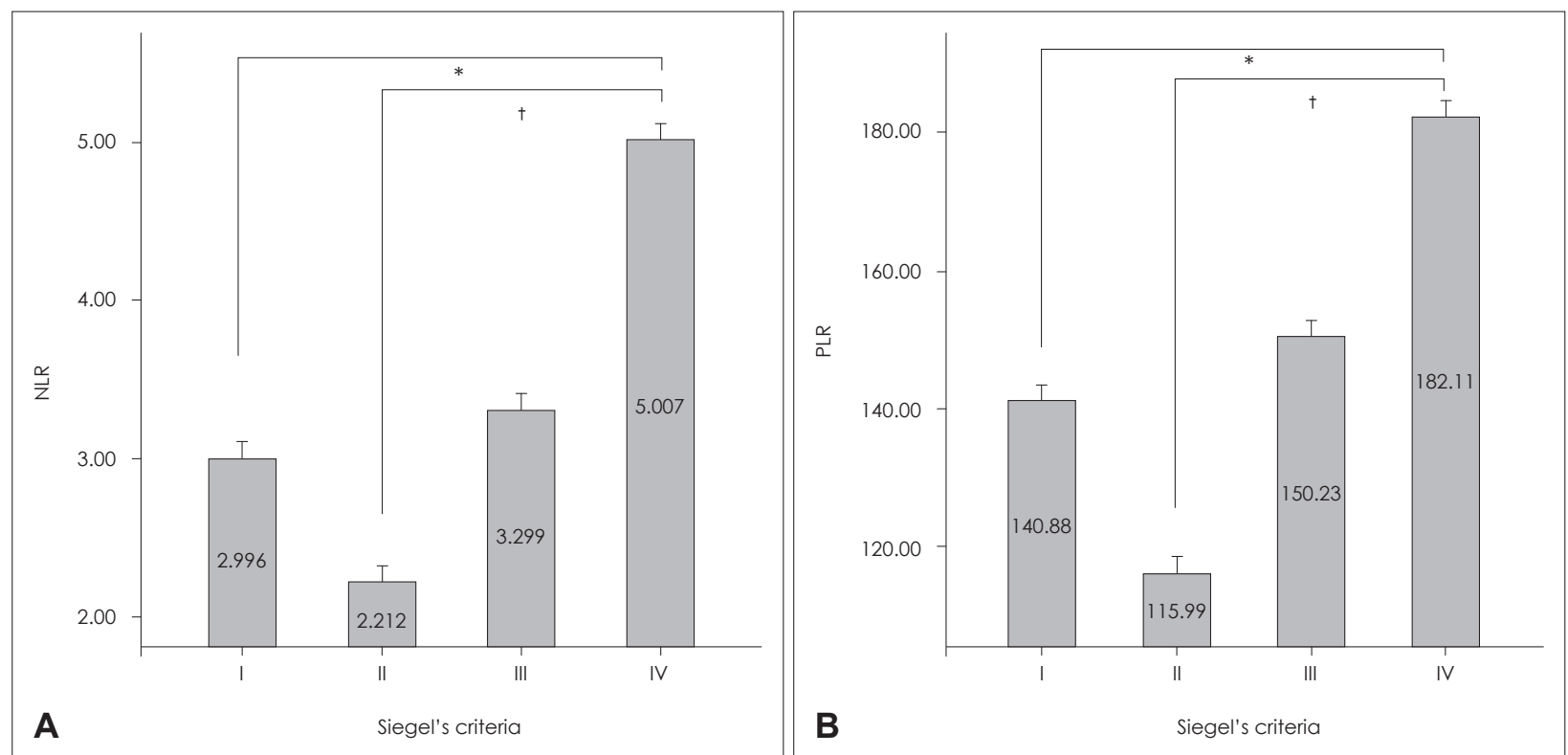

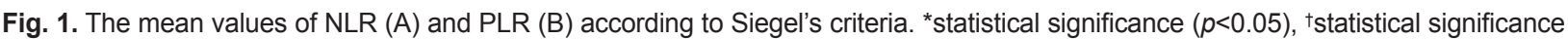
$(p<0.01)$. NLR: neutrophil-to-lymphocyte ratio, PLR: platelet-to-lymphocyte ratio.

Table 4. Adjusted risk factors between the recovered group and the unrecovered group

\begin{tabular}{|c|c|c|c|c|c|c|}
\hline \multirow{2}{*}{ Variable } & \multirow{2}{*}{$\beta$} & \multirow{2}{*}{ SE } & \multirow{2}{*}{$p$ value } & \multirow{2}{*}{$\exp (\beta)$} & \multicolumn{2}{|c|}{$95 \% \mathrm{Cl}$} \\
\hline & & & & & Lower & Upper \\
\hline PLR & 0.001 & 0.005 & 0.894 & 1.001 & 0.991 & 1.010 \\
\hline NLR & 0.307 & 0.132 & 0.020 & $1.359 *$ & 1.050 & 1.760 \\
\hline Viral marker & -1.360 & 0.820 & 0.868 & 1.146 & 0.230 & 5.717 \\
\hline Vertigo & -1.544 & 0.557 & 0.006 & $4.681^{*}$ & 1.571 & 13.954 \\
\hline
\end{tabular}

*statistical significance $(p<0.05)$. $\beta$ : standardized coefficients, SE: standard error, exp: Exponentiation, Cl: confidence interval, PLR: platelet-to-lymphocyte ratio, NLR: neutrophil-to-lymphocyte ratio

Sendai virus, human immunodeficiency virus 등이 있다. ${ }^{6)}$ 본 연구에서도 바이러스 감염과 관련하여 입원 시에 시행한 혈 액검사에 $\mathrm{HSV}, \mathrm{VZV}, \mathrm{CMV}$, influenza virus, HIV에 대한 검 사를 포함하였다. 그 결과 HSV 6명, VZV 3명, CMV 1명, influenza 1명, HIV 0명이 양성 소견을 보였으며, 이는 전체 103 명 중 11 명으로 $10.7 \%$ 에 해당한다. 청력 회복 정도에 따라 회 복군과 비회복군으로 나누고 각 군에서의 viral marker 양성 유무를 비교하였을 때, 통계적으로 의미 있는 결과를 보이지 않았다 $(p=0.726)$.

돌발성 난청은 고혈압과 당뇨와 같은 심혈관 위험 요인 또는 유전적 응고 감수성에 의한 미세순환계 변화의 결과로 나타 나기도 한다. ${ }^{34,35)}$ 혈액 점도의 증가와 adhesion molecules의 높은 발현 및 circulating endothelial progenitor cells의 감 소는 귀의 미세순환계 손상을 야기하고 이것은 청력 손실을 일으킨다. ${ }^{36-38)}$ 허혈 상태에서는 염증성 반응이 나타나고, 말초 혈류에서 허혈성 손상에 맞서 호중구 및 단핵구의 증가와 림 프구의 감소가 일어난다. ${ }^{39,40)}$

백혈구 수와 백혈구 백분율은 심혈관계 질환에서 염증 표
지자로서 이용된다. ${ }^{41,42)}$ NLR과 PLR은 말초혈액검사에서 쉽 게 계산되고, 실용적이며 저렴한 검사법이다. NLR은 심혈관 질환, 종양, 말기 신 질환, 궤양성 대장염, 충수염과 같은 염증성 질환에서 염증을 판별하는 신규 잠재 표지자로 사용되며, $39,40,43)$ 높은 NLR 수치는 높은 염증 상태를 의미한다. ${ }^{44)}$ 최근에는 호중구증가증 및 상대적 림프구감소증이 급성심부전 환자에 서 사망률에 대한 독립적 예측 인자로 알려졌다. ${ }^{45)}$ 혈소판은 죽 상동맥경화의 진행 과정에서 중요한 역할을 하는데, 혈소판 수 치가 높아지면 PLR 상승을 야기하고 이것은 혈관 관련 질환 의 높은 위험도와 관련이 있음이 밝혀졌다. ${ }^{11)}$ 돌발성 난청의 연구에서는 와우 손상과 염증 요인 사이에 의미 있는 상관관 계를 보였으며, ${ }^{46)}$ 또한 NLR 및 PLR이 돌발성 난청 환자군에 서 대조군에 비해 현저히 높은 값을 보였다. Özler ${ }^{20)}$ 는 돌발 성 난청 환자에서 NLR 값은 대조군에 비해 유의하게 높은 결과를 보였다고 하였으며 Ulu 등 ${ }^{21)}$ 도 비슷한 결과를 발표하 였다. Seo 등 ${ }^{22)}$ 은 NLR뿐만 아니라 PLR 값도 돌발성 난청 환자에서 대조군에 비해 높은 값을 보였다고 하였다.

이번 연구의 목적은 돌발성 난청 환자군에서 청력 회복 정 
도의 예후를 예측하는 데 혈액검사가 얼마나 유용한지에 대한 검증에 있다. 돌발성 난청에 대한 예후 인자를 알기 위해 청력 회복 정도에 따라 환자의 군을 회복군과 비회복군으로 나누 어 분석하였고, 그 결과 회복군과 비회복군에서 호중구, 림 프구, NLR, PLR 값이 유의하게 차이가 있다는 결과를 얻었 다. 회귀분석을 통한 추가 검증에서 $\mathrm{OR}$ 을 계산하였고 NLR 이 돌발성 난청에서 회복률과 연관이 있는 것으로 나타났다 $(\mathrm{OR}=1.359, p=0.020)$. 이런 결과는 PLR보다 NLR이 돌발성 난청의 예후를 더 잘 반영한다는 것을 보여준다. $\mathrm{SeO}$ 등 ${ }^{22)}$ 의 연구에서는 PLR이 돌발성 난청의 예후보다는 발병에 더 많 은 연관성을 가진다고 하였는데, 이것은 본 내용과 일치한다.

$\mathrm{CRP}$ 값과 청력 회복률을 분석하였는데, 그 이유는 $\mathrm{CRP}$ 와 interleukin(IL)-6의 수치가 높으면 직경 $10 \mathrm{~mm}$ 이하의 대뇌 경색(cerebral infarction)과 같은 조직 손상의 가능성이 높아 지는 경향이 있기 때문이다. ${ }^{47,48)}$ 하지만 본 연구에서는 CRP 값 은 청력 회복과 의미 있는 연관성을 가지지 않았으며, 따라서 이것은 돌발성 난청 환자에서 예후를 예측하는 데 유용한 생 체 표지자가 될 수 없을 것으로 생각된다. Masuda 등호도 돌 발성 난청의 발병 및 예후에 관련하여 염증 생체 표지자 중 high-sensitivity $\mathrm{CRP}(\mathrm{hCRP})$ 를 분석하였는데, 난청과 유의 한 차이는 없었다. 우리는 또 다른 염증 표지자인 ESR 값과 의 관련성도 분석하였으나 $\mathrm{CRP}$ 와 마찬가지로 청력 회복 정 도와 $\mathrm{ESR}$ 사이에는 통계적으로 유의한 연관성은 없었다.

이외에 돌발성 난청의 치료에 영향을 미치는 요인으로서 나이, 초기 청력도의 형태, 치료 시작까지 기간, 내원 시 난청의 정도, 현훈 동반의 유무 등이 보고되고 있다.,49,50) 60 세 이상 인 경우 돌발성 난청의 회복 정도가 떨어지는 것으로 알려져 있으며, 특히 $\mathrm{Byl}^{13)}$ 은 15 세 이하에서도 그 예후가 불량하다 고 하였다. Chon 등미은 초기 청력 손실이 클 경우 청력 회복 또한 나빠진다고 하였고, Sheehy ${ }^{49}$ 와 Xenellis 등 $^{18)}$ 은 초기 청 력도 형태에서 상승형일 때 청력 회복률이 좋다고 하였다. 발 병 후 치료 시작까지의 기간에 대하여 여러 논문에서는 7일 이 내 내원하여 치료하였을 때가 회복률이 좋았다고 하였는 데, ${ }^{2,51,52)}$ 본 연구에서는 1 주일 이내에 치료 시 회복군의 비율 이 더 높은 경향을 보였으나 통계적으로 유의하지는 않았다 $(p=0.098)$. 그 외 Laird와 Wilson ${ }^{16)}$ 은 현훈이 동반된 돌발성 난청에서 청력의 회복률이 감소한다고 하였고, 현훈이 동반 된 돌발성 난청 환자는 전체 환자의 26.9 37\% 정도로 보고되 었다. ${ }^{649)}$ 본 연구에서는 현훈이 동반된 경우가 $27.2 \%$ 로 유사 한 결과를 보였고 현훈이 동반된 경우가 비회복군에서의 비 율이 유의하게 높았다 $(p=0.030)$.

본 연구에서는 103 명의 돌발성 난청 환자의 치료에서 경구 methylprednisolone을 모든 환자에게 처방하였고, 경구 복용
으로 충분한 치료 효과를 얻지 못했을 때 추가 치료로 고실 내 스테로이드 주입술을 시행하였다. 구제 요법으로의 고실 내 스테로이드 주입술이 청력 개선에 영향을 줄 수 있으며, 치료의 병행 유무는 본 연구에서 치료 효과 판정에서 편의된 결과가 나타났을 가능성을 배제할 순 없다. 향후 동일한 치 료법에 대한 추가 분석이 필요할 것으로 생각된다.

본 연구의 제한점은 후향적인 연구라는 점, 집단 수가 적어 정규 분포를 따르지 않았다는 점, 그리고 치료 과정에서 고실 내 스테로이드 주입술의 병행 유무가 청력 개선에 얼마나 영 향을 미쳤는지 알 수 없다는 점이다. 또한 연구 대상 설정 시에 배제한 환자군 수가 많아 돌발성 난청 환자군 전체를 포괄 하는 결과를 도출하기는 어려움이 있을 것으로 보인다. 향후 좀 더 많은 환자군을 대상으로 하여 표준화된 치료로 분석 한 전향적인 연구가 필요하며 아울러 치료 이후의 혈액학적 검사결과에 대한 연구도 동반되면 좋을 것으로 사료된다.

\section{Acknowledgments}

This work was supported by a two-year Research Grant of Pusan National University.

\section{REFERENCES}

1) Hughes GB, Freedman MA, Haberkamp TJ, Guay ME. Sudden sensorineural hearing loss. Otolaryngol Clin North Am 1996;29 (3):393-405.

2) Mattox DE, Simmons FB. Natural history of sudden sensorineural hearing loss. Ann Otol Rhinol Laryngol 1977;86(4 Pt 1):463-80.

3) Merchant SN, Durand ML, Adams JC. Sudden deafness: is it viral? ORL J Otorhinolaryngol Relat Spec 2008;70(1):52-60; discussion 60-2.

4) Masuda M, Kanzaki S, Minami S, Kikuchi J, Kanzaki J, Sato H, et al. Correlations of inflammatory biomarkers with the onset and prognosis of idiopathic sudden sensorineural hearing loss. Otol Neurotol 2012;33(7):1142-50

5) Ryan AF, Harris JP, Keithley EM. Immune-mediated hearing loss: basic mechanisms and options for therapy. Acta Otolaryngol Suppl 2002;(548):38-43.

6) Shin SO, Choi YS, Lee DW, Yong MG, Jeon CW, Lee CS, et al. The therapeutic efficacy of combined antiviral treatment in sudden sensorineural hearing loss. Korean J Otorhinolaryngol-Head Neck Surg 2002;45(3):225-30.

7) Hiramatsu M, Teranishi M, Uchida Y, Nishio N, Suzuki H, Kato K, et al. Polymorphisms in genes involved in inflammatory pathways in patients with sudden sensorineural hearing loss. J Neurogenet 2012;26(3-4):387-96.

8) Hoffman M, Blum A, Baruch R, Kaplan E, Benjamin M. Leukocytes and coronary heart disease. Atherosclerosis 2004;172(1):1-6.

9) Ferroni P, Riondino S, Formica V, Cereda V, Tosetto L, La Farina F, et al. Venous thromboembolism risk prediction in ambulatory cancer patients: clinical significance of neutrophil/lymphocyte ratio and platelet/lymphocyte ratio. Int J Cancer 2015;136(5):1234-40.

10) Papa A, Emdin M, Passino C, Michelassi C, Battaglia D, Cocci F. Predictive value of elevated neutrophil-lymphocyte ratio on cardiac mortality in patients with stable coronary artery disease. Clin Chim Acta 2008;395(1-2):27-31.

11) Gary T, Pichler M, Belaj K, Hafner F, Gerger A, Froehlich H, et al. Platelet-to-lymphocyte ratio: a novel marker for critical limb ischemia 
in peripheral arterial occlusive disease patients. PLoS One 2013;8 (7):e67688

12) Kuhn M, Heman-Ackah SE, Shaikh JA, Roehm PC. Sudden sensorineural hearing loss: a review of diagnosis, treatment, and prognosis. Trends Amplif 2011;15(3):91-105.

13) Byl FM Jr. Sudden hearing loss: eight years' experience and suggested prognostic table. Laryngoscope 1984;94(5 Pt 1):647-61.

14) Chang NC, Ho KY, Kuo WR. Audiometric patterns and prognosis in sudden sensorineural hearing loss in southern Taiwan. Otolaryngol Head Neck Surg 2005;133(6):916-22.

15) Fetterman BL, Saunders JE, Luxford WM. Prognosis and treatment of sudden sensorineural hearing loss. Am J Otol 1996;17(4):529-36.

16) Laird N, Wilson WR. Predicting recovery from idiopathic sudden hearing loss. Am J Otolaryngol 1983;4(3):161-4.

17) Shaia FT, Sheehy JL. Sudden sensori-neural hearing impairment: a report of 1,220 cases. Laryngoscope 1976;86(3):389-98.

18) Xenellis J, Karapatsas I, Papadimitriou N, Nikolopoulos T, Maragoudakis $\mathrm{P}$, Tzagkaroulakis $\mathrm{M}$, et al. Idiopathic sudden sensorineural hearing loss: prognostic factors. J Laryngol Otol 2006;120(9):718-24.

19) Chon KM, Cho KS, Lee IW, Choi JS, Wang SG, Go EK. Sudden deafness in the elderly. Korean J Otorhinolaryngol-Head Neck Surg 2004;47(7):626-31.

20) Özler GS. Increased neutrophil-lymphocyte ratio in patients with idiopathic sudden sensorineural hearing loss. J Craniofac Surg 2014; 25(3): $260-3$

21) Ulu S, Ulu MS, Bucak A, Ahsen A, Yucedag F, Aycicek A. Neutrophilto-lymphocyte ratio as a new, quick, and reliable indicator for predicting diagnosis and prognosis of idiopathic sudden sensorineural hearing loss. Otol Neurotol 2013;34(8):1400-4.

22) Seo YJ, Jeong JH, Choi JY, Moon IS. Neutrophil-to-lymphocyte ratio and platelet-to-lymphocyte ratio: novel markers for diagnosis and prognosis in patients with idiopathic sudden sensorineural hearing loss. Dis Markers 2014;2014:702807.

23) Stachler RJ, Chandrasekhar SS, Archer SM, Rosenfeld RM, Schwartz SR, Barrs DM, et al. Clinical practice guideline: sudden hearing loss. Otolaryngol Head Neck Surg 2012;146(3 Suppl):S1-35.

24) Siegel LG. The treatment of idiopathic sudden sensorineural hearing loss. Otolaryngol Clin North Am 1975;8(2):467-73.

25) García-Berrocal JR, Trinidad A, Ramírez-Camacho R, Lobo D, Verdaguer M, Ibáñez A. Immunologic work-up study for inner ear disorders: looking for a rational strategy. Acta Otolaryngol 2005;125 (8):814-8.

26) Maier W, Fradis M, Kimpel S, Schipper J, Laszig R. Results of exploratory tympanotomy following sudden unilateral deafness and its effects on hearing restoration. Ear Nose Throat J 2008;87(8): 438-51.

27) Westmore GA, Pickard BH, Stern H. Isolation of mumps virus from the inner ear after sudden deafness. Br Med J 1979;1(6155):14-5.

28) Wilson WR. The relationship of the herpesvirus family to sudden hearing loss: a prospective clinical study and literature review. Laryngoscope 1986;96(8):870-7.

29) Jaffe BF. Viral causes of sudden inner ear deafness. Otolaryngol Clin North Am 1978;11(1):63-9.

30) Linthicum FH Jr, Doherty J, Berliner KI. Idiopathic sudden sensorineural hearing loss: vascular or viral? Otolaryngol Head Neck Surg 2013;149(6):914-7.

31) Jaffe BF, Penner JA. Sudden deafness associated with hypercoagulation. Trans Am Acad Ophthalmol Otolaryngol 1968;72(5):774-8.

32) Schuknecht HF, Donovan ED. The pathology of idiopathic sudden sensorineural hearing loss. Arch Otorhinolaryngol 1986;243(1):1-15.
33) Yoon TH, Paparella MM, Schachern PA, Alleva M. Histopathology of sudden hearing loss. Laryngoscope 1990;100(7):707-15.

34) Weng SF, Chen YS, Liu TC, Hsu CJ, Tseng FY. Prognostic factors of sudden sensorineural hearing loss in diabetic patients. Diabetes Care 2004;27(10):2560-1.

35) Rudack C, Langer C, Stoll W, Rust S, Walter M. Vascular risk factors in sudden hearing loss. Thromb Haemost 2006;95(3):454-61.

36) Mosnier I, Stepanian A, Baron G, Bodenez C, Robier A, Meyer B, et al. Cardiovascular and thromboembolic risk factors in idiopathic sudden sensorineural hearing loss: a case-control study. Audiol Neurootol 2011;16(1):55-66.

37) Chau JK, Lin JR, Atashband S, Irvine RA, Westerberg BD. Systematic review of the evidence for the etiology of adult sudden sensorineural hearing loss. Laryngoscope 2010;120(5):1011-21.

38) Quaranta N, Ramunni A, De Luca C, Brescia P, Dambra P, De Tullio $\mathrm{G}$, et al. Endothelial progenitor cells in sudden sensorineural hearing loss. Acta Otolaryngol 2011;131(4):347-50.

39) Ross AM, Hurn P, Perrin N, Wood L, Carlini W, Potempa K. Evidence of the peripheral inflammatory response in patients with transient ischemic attack. J Stroke Cerebrovasc Dis 2007;16(5):203-7.

40) Emsley HC, Smith CJ, Tyrrell PJ, Hopkins SJ. Inflammation in acute ischemic stroke and its relevance to stroke critical care. Neurocrit Care 2008;9(1):125-38.

41) Tamhane UU, Aneja S, Montgomery D, Rogers EK, Eagle KA, Gurm HS. Association between admission neutrophil to lymphocyte ratio and outcomes in patients with acute coronary syndrome. Am J Cardiol 2008;102(6):653-7.

42) Arruda-Olson AM, Reeder GS, Bell MR, Weston SA, Roger VL. Neutrophilia predicts death and heart failure after myocardial infarction: a community-based study. Circ Cardiovasc Qual Outcomes 2009;2(6): 656-62.

43) Chen TM, Lin CC, Huang PT, Wen CF. Neutrophil-to-lymphocyte ratio associated with mortality in early hepatocellular carcinoma patients after radiofrequency ablation. J Gastroenterol Hepatol 2012;27(3):553-61.

44) Imtiaz F, Shafique K, Mirza SS, Ayoob Z, Vart P, Rao S. Neutrophil lymphocyte ratio as a measure of systemic inflammation in prevalent chronic diseases in Asian population. Int Arch Med 2012;5(1):2.

45) Rudiger A, Burckhardt OA, Harpes P, Müller SA, Follath F. The relative lymphocyte count on hospital admission is a risk factor for long-term mortality in patients with acute heart failure. Am J Emerg Med 2006;24(4):451-4.

46) Fujioka M, Kanzaki S, Okano HJ, Masuda M, Ogawa K, Okano H. Proinflammatory cytokines expression in noise-induced damaged cochlea. J Neurosci Res 2006;83(4):575-83.

47) Ridker PM. Inflammatory biomarkers and risks of myocardial infarction, stroke, diabetes, and total mortality: implications for longevity. Nutr Rev 2007;65(12 Pt 2):S253-9.

48) Hoshi T, Kitagawa K, Yamagami H, Furukado S, Hougaku H, Hori M. Relations of serum high-sensitivity C-reactive protein and interleukin-6 levels with silent brain infarction. Stroke 2005;36(4): 768-72.

49) Sheehy JL. Vasodilator therapy in sensory-neural hearing loss. Trans Am Laryngol Rhinol Otol Soc 1960;1960:570-602.

50) Byl FM. Seventy-six cases of presumed sudden hearing loss occurring in 1973: prognosis and incidence. Laryngoscope 1977;87(5 Pt 1): 817-25.

51) Byl FM. Sudden hearing loss research clinic. Otolaryngol Clin North Am 1978;11(1):71-9.

52) Meyerhoff WL. Sudden deafness. Tex Med 1976;72(1):80-3. 